\title{
Perceptions of Academic Leaders on the Factors Influencing Academic Leadership Role and Challenges in Academic Improvement for Effective Performance of Health Sciences Institutes
}

\author{
Kalidas Dattatraya Chavan \\ Post Doctoral Fellow, College of Allied Health Sciences, \\ Shrinivas University, Mangaluru, Karnataka, India- 575001. \\ Email: kdchavan17@gmail.com
}

Area/Section: Health Sciences.

Type of the Paper: Research Paper.

Type of Review: Peer Reviewed as per $|\mathrm{C}| \mathrm{O}|\mathrm{P}| \mathrm{E} \mid$ guidance.

Indexed in: OpenAIRE.

DOI: http://doi.org/10.5281/zenodo.3613377.

Google Scholar Citation: IJHSP

\section{How to Cite this Paper:}

Chavan., Kalidas Dattatraya. (2019). Perceptions of Academic Leaders on the Factors Influencing Academic Leadership Role and Challenges in Academic Improvement for Effective Performance of Health Sciences Institutes. International Journal of Health Sciences and Pharmacy (IJHSP), 3(2), 23-29.

DOI:https://doi.org/10.5281/zenodo.3613377.

International Journal of Health Sciences and Pharmacy (IJHSP)

A Refereed International Journal of Srinivas University, India.

IFSIJ Journal Impact Factor for 2019-20 = 3.968

(C) With Author.

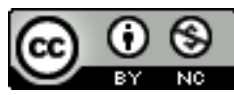

This work is licensed under a Creative Commons Attribution-Non Commercial 4.0 International License subject to proper citation to the publication source of the work.

Disclaimer: The scholarly papers as reviewed and published by the Srinivas Publications (S.P.), India are the views and opinions of their respective authors and are not the views or opinions of the SP. The SP disclaims of any harm or loss caused due to the published content to any party. 


\title{
Perceptions of Academic Leaders on the Factors Influencing Academic Leadership Role and Challenges in Academic Improvement for Effective Performance of Health Sciences Institutes
}

\author{
Kalidas Dattatraya Chavan \\ Post Doctoral Fellow, College of Allied Health Sciences, \\ Shrinivas University, Mangaluru, Karnataka, India- 575001. \\ Email: kdchavan17@gmail.com
}

\begin{abstract}
India is ranked at the third largest higher education system in the world in terms of students and for improvement of quality of education in Health Sciences Institutes, there is direct need of academic leadership.Earlier researchers have documented the reasons for the lack of proficiency and emphasis on leadership in the academics. This study was an attempt is made to understand the perceptions of academic leaders of various levels on the factors Influencing Academic Leadership Role and Challenges in Academic Improvement for Effective Performance of Health Sciences Institutes. A cross sectional study was conducted with simple random sampling technique among 416 Heads of the academic departments in a college, 43 Dean/Principals of the colleges and 03 Vice Chancellors of the universities in Health sciences institutes of Maharashtra state during August, 2019 to December, 2019.The data analysis SPSS and statistical test Kendall's W were used. Study concluded that role of the Government (and its agencies) and Council regulations and guidelines are the main influencing factors for delivering the role of academic leaders. Insufficient financial assistance when required perceived as main challenges in academic improvement of institute for effective performance.
\end{abstract}

Keywords: Academic leadership, Health sciences institutes, Academic improvement, effective performance.

\section{INTRODUCTION :}

Role of leadership and its effectiveness is an area that is continuously drawing and stimulating adequatefocus in scientific literature[1]. The effectiveness and quality of academic leadership largely influences the quality of education, which directly impacts the learning outcomes of the students.Academic leadership has become an important phenomenon for higher education as we are aiming to achieve certain global standards.

Although setting up common understanding of what actually mean by an effective leadership is a complex undertaking[2], many researchers have laid down the definitions and concepts of academic leadership for effectiveness of higher education. Although it is understood the role of academic leadership is much more important in imparting global standards into it, there are many challenges and factors affecting the academic leadership. In academics, there are various factors since long time who have been affecting the effectiveness and success of academic leadership.

Researchers have documented the reasons for the lack of proficiency and emphasis on leadership in the academics. Lack of time for executing instructional activities, unrealistic expectations and huge paperwork were the reasons cited for the shortfall[3]. Many researchers studied various challenges and tried to understand the complex phenomenon. Mrig, 2017 stated that the average tenure for the head of the community college was just 2.8 years as reported by the league for innovations 
in the community college trends[4]. Once the academic leaders find themselves in the role, the lack of training for the academic chairs is another important challenge for academic leaders[5].

Looking at the literature review and the importance of academic leadership, it is important to understand the challenges of academic leadership in India context. Hence, in present study an attempt was made to understand the perceptions of academic leaders of various levels on the Factors Influencing Academic Leadership Role and Challenges in Academic Improvement for Effective Performance of Health Sciences Institutes.

\section{METHODOLOGY :}

Study Design -The study was a part of large cross-sectional study to understand the perceptions of the academic leaders of various levels on factors affecting academic leadership.

Study Setting - The study setting was Health Sciences Institutes/Universities offering formal degree programs of various disciplines in the state of Maharashtra including state funded, private and those affiliated to deemed to be universities.

Study Period: The study was conducted from August, 2019 to December, 2019.

Study Population: The study population for the current study was the academic leaders in the health sciences institutions serving in different capacities starting from Heads of the academic departments in a college, Dean/Principals of the colleges and Vice Chancellors of the Universities.

Sample Size -About $15 \%$ of the available academic leaders were initially invited to participate in the study. Considering a third of them will drop out and two third will participate, final sample consisted minimum $10 \%$ of the total available academic leaders. There were about 10 deemed to be Universities, one State University and about 398 health science institutes in the state. Vice Chancellors of 3 Universities were included in the study. However, minimum $10 \%$ Deans/Principal's and HOD's were included in the study. Hence, the total minimum sample size for the study was 3 Vice Chancellor, 43 Dean's/Principal's and 416 HOD's.
Sampling Technique-The list of all eligible personnel those fit in the definition of academic leaders along with their contact details was collected and compiled from various sources. From this list the required number of participants were selected using simple random sampling technique.

Data Collection and Analysis- The main objective of the study was to understand the perceptions of academic leaders on the factors influencing academic leadership role and challenges in academic improvement for effective performance of health sciences institutes[6]. Accordingly, the data collection tool was developed and validated taking into consideration the important capabilities. Selected participants were invited to participate in the study by sending an online link to fill the survey questionnaire on 1 to 5 Likert scale. Data was collected through online questionnaire. The analysis was performed using SPSS and statistical test Kendall's W was used to understand the level of agreement among the participants.

\section{RESULTS AND DISCUSSION :}

The study basically intended to understand and explore the perceptions of academic leaders on various aspects of Academic Leadership for Effective Performance of Health Sciences Institutes. The study has received response from 687 academic leaders out of which 318 were females and 369 were males. Out of 687 respondents, $77.9 \%$ were Head of the Departments, 21.7 \% were Dean's/Principals and $0.4 \%$ were Vice Chancellors of the universities. The distribution of respondents as per their discipline shows that maximum respondents i.e. $31.1 \%$ were from Ayurveda discipline followed by Nursing (22.1\%), Homoeopathy (18.2 \%), Modern Medicine (13.4\%), Allied Health (9 \%) and Dentistry (6.1\%).

3.1 The factors influencing academic leadership role :

Influence is a significant concept for leaders, without it there would be no change. Influence is the key in organizations with shared or distributes leadership processes in place[7]. Leadership in academic setup is affected by several factors within or outside the institutes. About 159 out of 687 (i.e. 23.1\%) respondents said that "Role of the Government (and its 
agencies)" as the major factor influencing their current role. "General Council Regulations and guidelines" was the next important influencing factor, as perceived by $24 \%$ respondents. 19.2 $\%$ respondents of the study perceived Growing competition (Local and International) as the third important factor which has influence on their day to day activities.Around $18.2 \%$ respondents opined that they face difficulty in managing good quality staff. Financial Management of the organization has been rated as fifth major influencing factor by the academic leaders.Kendall's W was 0.009 for this parameter, signifying the less degree of agreement amongst the participants.

Table 1: Factors influencingthe role of academic leaders.

\begin{tabular}{|l|c|c|c|c|c|c|c|c|c|c|}
\hline Factors influencing & \multicolumn{10}{|c|}{ Rank } \\
\cline { 2 - 10 } & $\mathbf{1}$ & $\mathbf{2}$ & $\mathbf{3}$ & $\mathbf{4}$ & $\mathbf{5}$ & $\mathbf{6}$ & $\mathbf{7}$ & $\mathbf{8}$ & $\mathbf{9}$ & $\mathbf{1 0}$ \\
\hline $\begin{array}{l}\text { Role of the Government } \\
\text { (and its agencies) }\end{array}$ & 159 & 84 & 58 & 35 & 51 & 45 & 43 & 52 & 53 & 107 \\
\hline $\begin{array}{l}\text { Council Regulations and } \\
\text { guidelines }\end{array}$ & 116 & 165 & 69 & 48 & 41 & 48 & 47 & 40 & 90 & 23 \\
\hline $\begin{array}{l}\text { Growing competition } \\
\text { (Local and International) }\end{array}$ & 47 & 61 & 132 & 74 & 67 & 52 & 67 & 93 & 48 & 46 \\
\hline $\begin{array}{l}\text { Finding and retaining high } \\
\text { quality staff }\end{array}$ & 113 & 76 & 94 & 125 & 63 & 51 & 66 & 31 & 35 & 33 \\
\hline Financial Management & 34 & 64 & 75 & 88 & 145 & 113 & 54 & 40 & 42 & 32 \\
\hline $\begin{array}{l}\text { Maintaining specific } \\
\text { institutional Image }\end{array}$ & 40 & 40 & 67 & 97 & 109 & 159 & 66 & 44 & 37 & 28 \\
\hline $\begin{array}{l}\text { Administrative pressure } \\
\text { from sponsoring } \\
\text { body/trust }\end{array}$ & 32 & 34 & 50 & 91 & 57 & 59 & 153 & 77 & 81 & 53 \\
\hline $\begin{array}{l}\text { Increased student } \\
\text { diversity }\end{array}$ & 31 & 48 & 74 & 49 & 67 & 61 & 85 & 150 & 70 & 52 \\
\hline $\begin{array}{l}\text { Pressure of completing } \\
\text { enrollment/admissions }\end{array}$ & 39 & 60 & 36 & 41 & 32 & 50 & 59 & 95 & 163 & 112 \\
\hline $\begin{array}{l}\text { Declining quality of } \\
\text { academic and research }\end{array}$ & 77 & 55 & 32 & 39 & 54 & 49 & 45 & 64 & 72 & 200 \\
\hline
\end{tabular}

It is evident from the fact that, the government policies in recent past have influenced the higher education and the academic leaders there off. This is because of the uncertainty created by the policy makers on various aspects of higher education reforms. To take the higher education at an international level is always a priority for governments across the world, it is because of the academic, political, social and economic benefits associated with it[8].Hence, government is focusing on a major shift in higher education which might have influenced the role of academic leaders in Indian context. Increased student diversity was assigned eighth rank by most of the participant'si.e., $21.8 \%$ in the study. Scott et.al., 2008 have also reported the influence by student diversity on the leadership role[6]. The academic leaders including Dean, Head of the dept. and Vice chancellors from their study have also indicated that diversity in the students affects the leadership role in higher education. The results are in agreement with Guthire, 2019 who reported that the biggest challenge for colleges and academic leaders is to educate and train the student from diverse background[9].The enrolments in the school level has increased and the supply of higher education institutes is not sufficient to meet the increasing demand in the country[10].Although the overall enrollment in higher education is less as compared to that of pre higher education, there is always a pressure on the academic leaders to fill the total strength of students and hence, the respondents might have opined it as a challenge.The leadership qualities also include research as an important component, however 
producing research outcome has been also considered as a major challenge by the academic leaders as mentioned in the earlier studies[11].

3.2. Challenges in academic improvement of institute for effective performance as perceived by academic leaders :
Every academic institute goes through the hard phases of development where certain factors or challenges act against the academic improvement of the institute for effective performance.

Table 2 :Challenges / Hurdles in academic improvement of Institute

\begin{tabular}{|l|c|c|c|c|c|c|c|c|c|c|}
\hline \multirow{2}{*}{ Challenges / Hurdles } & \multicolumn{7}{|c|}{ Rank } \\
\cline { 2 - 11 } & $\mathbf{1}$ & $\mathbf{2}$ & $\mathbf{3}$ & $\mathbf{4}$ & $\mathbf{5}$ & $\mathbf{6}$ & $\mathbf{7}$ & $\mathbf{8}$ & $\mathbf{9}$ & $\mathbf{1 0}$ \\
\hline $\begin{array}{l}\text { Management/ } \\
\text { Government policies }\end{array}$ & 217 & 68 & 47 & 48 & 48 & 57 & 42 & 55 & 44 & 61 \\
\hline $\begin{array}{l}\text { Lack of timely and } \\
\text { sufficient financial } \\
\text { assistance }\end{array}$ & 98 & 167 & 76 & 50 & 54 & 45 & 51 & 54 & 59 & 33 \\
\hline $\begin{array}{l}\text { Frequently changing } \\
\text { guidelines by regulatory } \\
\text { authorities }\end{array}$ & 54 & 106 & 168 & 69 & 69 & 41 & 50 & 68 & 34 & 28 \\
\hline $\begin{array}{l}\text { Difficulty in getting/ } \\
\text { retaining/ managing } \\
\text { teaching staff }\end{array}$ & 76 & 74 & 84 & 163 & 61 & 53 & 85 & 32 & 22 & 37 \\
\hline $\begin{array}{l}\text { Multiple Reporting } \\
\text { protocols (to Government } \\
\text { / other authorities) }\end{array}$ & 21 & 46 & 75 & 76 & 178 & 127 & 51 & 42 & 49 & 22 \\
\hline $\begin{array}{l}\text { Time consumed by non- } \\
\text { academic activities }\end{array}$ & 64 & 55 & 58 & 75 & 102 & 163 & 69 & 49 & 30 & 22 \\
\hline $\begin{array}{l}\text { Students activities } \\
\text { affecting academics }\end{array}$ & 25 & 41 & 58 & 73 & 63 & 78 & 186 & 80 & 51 & 32 \\
\hline Local political issues & 37 & 36 & 48 & 35 & 23 & 28 & 58 & 158 & 118 & 146 \\
\hline $\begin{array}{l}\text { Difficulties in promoting } \\
\text { quality research }\end{array}$ & 39 & 67 & 49 & 54 & 52 & 55 & 54 & 99 & 172 & 46 \\
\hline $\begin{array}{l}\text { Difficulties in attracting } \\
\text { foreign university } \\
\text { collaborations }\end{array}$ & 57 & 27 & 25 & 43 & 36 & 39 & 40 & 51 & 108 & 261 \\
\hline Kendall's W = 0.134 & & & & & & & & & \\
\hline
\end{tabular}

India is following China and USA and has world's third largest education system. In order to compete in global economy, India is striving in the areas that require highly trained professionals and in this situation the quality of higher education becomes increasingly important [12].Hence, the challenges for academic leaders for improvement in higher education system becomes important. Most of the participants, 217 (i.e. $31.6 \%$ ) respondents perceived "Management/ Government policies" as the challenge / hurdle in academic leadership development. "Lack of timely and sufficient financial assistance" was the next important challenge/hurdle, as perceived by
$24.3 \%$ respondents.Most of the participants felt that frequently changing guidelines by regulatory authorities is most important challenge in academic improvement of institute for effective performance and this was ranked third by $24.5 \%$ participants. Difficulty in getting/ retaining/ managing teaching staff was perceived as an important hurdle by 23.7 $\%$ respondents and was placed at fourth place. Multiple Reporting protocols (to Government / other authorities) was placed at fifth level and $25.9 \%$ respondents felt that it is also one of the major challenges in academic improvement of the institute. Kendall's W was 0.134 , signifying the fair degree of agreement 
amongst the participants.

The financial behaviour of the higher education is one of the most complex phenomena. It has been seen in last 30 years that the higher education has been not given enough share from the public purse since the great recession[13]. In order to assess movement of higher education system, it becomes important to understand the financing of higher education system[14].Hence, for all higher education institutes, continuous financial support has been always a big question. The academic leaders therefore rightly raised the concern about lack of timely and sufficient financial assistance as a challenge for academic improvement of institute. Difficulty in retaining teaching staff has been seen in almost all the higher educational institutes in recent past.

It has been since many years, that the inability of state education system towards attracting and retaining the well qualified staff and shortage of staff posing the serious challenges[12].Poor connection of Indian higher educational system to the research centre has been recognized as one important challenge of higher education. The same challenge has been perceived by the respondents in the present study[12].Another reason for research promotion becomes difficult could be managing the research talent by Indian academic institutions. Recruiting the top research talents is also a major challenge to the large universities. Senior professors are leaving the academic for opportunities in to industry, where they will have access to the resource and data to work on most important topics and problems [9].

\section{CONCLUSION :}

It is concluded from present study that; the academic leaders of the health sciences institutes perceived role of the Government (and its agencies) and Council regulations and guidelines as main influencing factors for delivering the role of academic leaders. However, Management/ Government policies and Lack of timely and sufficient financial assistance were perceived as main challenges in academic improvement of institute for effective performance.

\section{REFERENCES :}

[1] Waldman, D. A., Ramirez, G. G., House, R. J., \& Puranam, P. (2001). Does Leadership Matter? CEO Leadership Attributes and Profitability under Conditions of Perceived Environ Mental Uncertainty', Academy of Management Journal, 44, 134-143.

[2] Goski Alabi \& Joshua Alabi (2014). Understanding the Factors that Influence Leadership Effectiveness of Deans in Ghana. JHEA/RESA,12(1), 111-132.

[3] Mauricio David (2017). Four Instructional Leadership Skills Principals Need. Educational Leadership. http://education.cuportland.edu/blog/edleadership/ fourinstructionalleadership - skills- principalsneed/.

[4] MrigAmit (2017). Four Stats That will Impact Higher Ed in 2017. Academic Impressions. http://www.academicim pressions. com/news/four-stats-willimpact-higher-ed-2017.

[5] KearnyPamalyn (2014). Challenges of the Academic Department Chair in Occupational Therapy. http://www.newfoundations.com/ Org Theory/ Kearney 721Sp06.html.

[6] Scott Geoff, Hamish Coates \& Michelle Anderson (2008). Learning Leaders in times of Change-Academic Leadership Capabilities for Australian Higher Education. University of Western Sydney and Australian Council for Educational Research. ISBN: 978-0-86431-978-4.

[7] Anderson K.D. (2008). Transformational teacher leadership in rural schools. The Rural Educator, 8-17.

[8] Craciun D. (2018). National Policies for Higher Education Internationalization: A Global Comparative Perspective. In: Curaj A., Deca L., Pricopie R. (eds) European Higher Education Area: The Impact of Past and Future Policies. Springer, Cham.

[9] Guthrie Kevin M. (2019).Challenges to Higher Education's Most Essential 
Purposes. Ithaka $\quad S+R$.

DOI: https://doi.org/10.18665/sr.311221.

[10] Sheikh Younis Ahmad (2017). Higher Education in India: Challenges and Opportunities. Journal of Education and Practice. 8, (1), 39-42.

[11] Murray, D., Goedegebuure, L., van Liempd, H.-G. and Vermeulen, M. (2014). Leadership needs in international higher education in Australia and Europe. Final Report of a Delphi Study, International Education Association of Australia (IEAA) and the European Association for International Education (EAIE), Melbourne and Amsterdam.

[12] Singh J D. (2011). Higher Education in India - Issues, Challenges and Suggestions. Higher Education', LAMBERT. Academic Publishing, Germany, pp.93-103. ISBN: 978-3-84651753-6.

[13] James J. Duderstadt (2009). Current Global Trends in Higher Education and Research: Their Impact on Europe, Dies Academics. https://core.ac.uk/ download/pdf/3146623.pdf.

[14] UGC (2008). Higher Education in India Issues Related to Expansion, Inclusiveness, Quality and Finance. University Grants Commission New Delhi. Printed and Published by Secretary, University Grants Commission, Bahadur Shah Zafar Marg, New Delhi 110002. Chapter 10-Financial Requirements in Higher, Education during XI Plan Period By Sudhanshu Bhushan. pp-215-276. 